\title{
DPF1 Gene
}

National Cancer Institute

\section{Source}

National Cancer Institute. DPF1 Gene. NCI Thesaurus. Code C157304.

This gene is involved in the regulation of cell survival. 